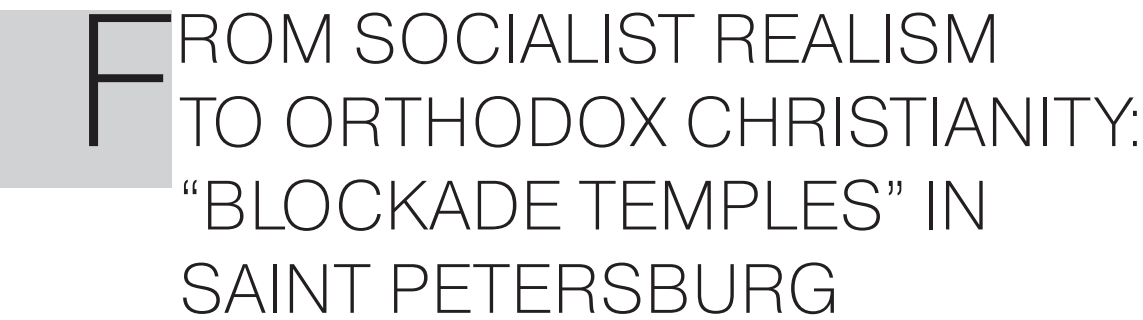

\title{
Tatiana Voronina
}

Tatiana Voronina is a PhD candidate and research fellow at the University of Zurich, Switzerland. Address for correspondence: Universität Zürich, Forschungsstelle für Sozial- und Wirtschaftsgeschichte, Rämistrasse 64, 8001 Zurich, Switzerland. tatiana.voronina@hist.uzh.ch.

I am grateful to Alexis Peri for assisting with translation of this article.

The article, based on the analysis of architectural and memorial complexes dedicated to the Siege of Leningrad in Saint Petersburg, investigates the processes of formation and transformation of historical memory of this event in the urban space. The secular language of the artistic representation of the blockade created during the years of the USSR was instrumentalized by agents of the politics of history on the eve of perestroika and reinterpreted through the categories of Orthodox Christianity in contemporary Russia. Following the cultural transformations that took place during perestroika, I identify new actors of the politics of history: organizations of blockade survivors, Russian nationalists, and the Russian Orthodox Church. They were the driving force behind many memorials and commemorative signs dedicated to the Blockade of Leningrad in and around Saint Petersburg in the 1990s and early 2000s. The construction of Russian Orthodox churches dedicated to the memory of the blockade, like the Church of the Assumption of the Blessed Virgin Mary on Malaia Okhta and the Church of All Saints Resplendent in the Russian Land in Victory Park, testify to the emergence of a new language of historical commemoration in the post-Soviet Saint Petersburg. It also indicates the inclusion of the blockade in the category of events significant to the historical narrative of the Russian Orthodox Church. Using the example of the Russian Orthodox Church's policy regarding commemoration of the blockade in the 1990s, I outline the reasons why a formerly marginal agent of the politics of history not only was able to mark its presence in the city's cultural space, but also began to claim the place of the most influential interpreter of the past in contemporary Russia. The study is based on visual analyses of several memorials dedicated to the Blockade of Leningrad, the circumstances of the creation of monuments and other commemorative markers, their location in the city, and the discursive significance attached to memorials by the city's community. The article is written at the intersection of research in history of memory and cultural studies.

Keywords: Historical Memory; Siege of Leningrad; Architecture; Monuments; Commemoration; Russian Orthodox Church; Associations of the Siege Survivors 
The tourist who comes to Saint Petersburg (called Petrograd in 1914-1924 and Leningrad in 1924-1991) for the first time expects to see not only the brilliant architecture of the imperial capital but also a large number of monuments and memorials dedicated to the Siege of Leningrad during the Second World War. The history of the city during the war is one of the best-developed areas of tourism dedicated to the Soviet period. At the same time, if a tourist orders a city tour from a modern travel agency, the route and the set of memorials and places on the itinerary will be very different from the Leningrad excursions of 30 years ago. Along with the Piskarevskoe Memorial Cemetery ${ }^{1}$ and the Monument to the Heroic Defenders of Leningrad, ${ }^{2}$ which have long served as the main places of memory surrounding this event, tourists will be invited to visit the blockade temples on Malaia 0khta ${ }^{3}$ and at Victory Park in the Moscow district of Saint Petersburg. ${ }^{4}$

During perestroika and in the time since, the memory of the Siege of Leningrad has been an important component of Soviet and Russian identity. It developed within the framework of the socialist-realist canon and has been an object of increased interest from new actors participating in commemoration-be they associations of the siege survivors or Russian Orthodox activists. Their interpretations are reflected in urban sculptures and new memorials dedicated to the blockade, including the temples built in 1996 and 2010 in the Church of the Assumption of the Blessed Virgin Mary. This article examines the transformation of the city's cultural landscape on the eve of perestroika and in the first postperestroika decades. It asks: How, in the secular history of the blockade told in secular Soviet language, did Russian Orthodox shrines become central? How did this affect interpretations of this event?

\section{METHODOLOGY AND THEORETICAL FRAMEWORK}

I draw on Maurice Halbwachs's theory of "social memory" about the connections between memory and group identity as well as on subsequent theories developed by his students (Halbwachs 2007). Particularly helpful is the research Halbwachs inspired on possible causal links between memory and the nation. This literature is divided into two camps. The two sides fundamentally disagree over whether a majority or a minority group tends to be "the carrier of memory." In other words, they disagree about who determines how a nation's history and cultural traditions will be preserved (Nora 1989; Assmann 1999).

${ }_{1}^{1}$ Piskarevskoe Memorial Cemetery is the memorial complex designed by Aleksandr Vasil'ev and Evgenii Levinson dedicated to the victims of the Siege of Leningrad.

${ }^{2}$ The Monument to the Heroic Defenders of Leningrad is a one of the biggest memorials in Saint Petersburg dedicated to the siege and defense of Leningrad during WWII. It was created by a group of architects, led by Sergei Speranskii, Valentin Kamenskii, and sculptor Mikhail Anikushin, on Victory Square at the entrance to Moskovskii Prospekt.

${ }^{3}$ Malaia Okhta is the historical name of one of the districts of Saint Petersburg. Now it is a part of the city's Krasnogvardeiskii District on the right bank of Neva.

${ }^{4}$ Victory Park is a public park in Moskovskii District of Saint Petersburg. It is situated in the southern part of the city. 
The first approach argues for majority influence. It focuses on key sites of national history (lieux de mémoire). It emphasizes state or national elites as the main agents who try to impose certain visions of the past onto social consciousness (Shenk 2007; Danilova 2016). These agents create certain "frames of remembrance" and select certain tropes and categories for historical representation. They also convey to society why it is important to remember that particular event. One problem with this approach to collective memory, however, is that it does not explain how changes occur over time and how multiple collectively held memories can coexist. Still, this theoretical approach does help us understand the longue durée of certain cultural characteristics, which shape the way the past is represented. It assumes that events that are kept in the historical consciousness of a society can change over time, but that the forms of narrating them are more or less stable. Irina Paperno (2009), for instance, has found that the stylistics of memoirs from Soviet era adhere closely to the most famous of Russian remembrances, Alexander Herzen's My Past and Thoughts.

The second approach focuses on groups that actively produce their own versions of the past. These groups could be ethnic, religious, or social. Although I contend that there was a Soviet historical tradition or paradigm for representing the past, this does not preclude the possibility that multiple versions of the past in collective memory exist. The ways of remembering are not dominated by one agent (the state or national elites for instance) but have many "carriers of memory." Rather than argue exclusively for majority influence, as the first school does, I support the idea that there are multiple agents, many from minority groups, who formulate their own vision of the past and then strive to legitimize it in the eyes of the majority. In other words, I adopt a "dynamic approach" towards memory, one that acknowledges majority and minority groups in order to explain how conflicting historical visions can emerge within one culture or nation. At various moments and in various arenas, one group is simply more visible and, thus, influential than others (Misztal 2003).

I hypothesize that during perestroika vocal minorities (groups of activists from associations of the siege survivors, the Russian Orthodox Church, dissidents from the Memorial Society, and others) were the driving force behind the evolving memory of WWII and that their historical narratives were inextricably linked to their efforts to obtain legitimacy in society. Minority groups became especially important during perestroika because during that time political actors who previously had been excluded from public discourse were given the opportunity to become prominent voices in society.

For a long time the memory of the Siege of Leningrad, which lasted from September 8, 1941, until January 26, 1944, developed within the framework of official state discourse about WWII (Kirschenbaum 2006). This discourse had several important features. First, most public presentations of the siege were controlled by authorities through censorship and repression (Blum 2005). Second, Soviet memorialization of war victims had a secular character. Accordingly, Soviet-era memorials in Leningrad about the siege were devoted to heroicizing the victims without giving preference to any religion (Merridale 2002; Paperno 2009). Thirdly, the official discourse was influ- 
enced by socialist realism, which became the chief "frame of memory" for all public presentations of the Siege of Leningrad during the Soviet era (Voronina 2018).

As a result of socialist realism's influence, the Siege of Leningrad was never just a horrible, traumatic experience for the population. It was a sort of initiation rite, an ordeal during which the Soviet people, and Leningraders in particular, showed their best qualities and helped destroy German fascism. The blockade was never presented as a trauma. It was always a heroic feat (Tumarkin 1994). This limited the range of possible ways to represent the Siege of Leningrad during the Soviet period. And, as the Russian Orthodox Church (ROC) was a marginalized organization during Soviet times, a public religious interpretation was most improbable.

\section{MEMORIAL COMPLEXES AS PLACES OF MEMORY}

Since Pierre Nora's (1989) classic study of lieux de mémoire, memorial complexes have become regular objects of study for historians. Understanding memorials and monuments as places of memory has allowed researchers to illuminate the transformation of historical politics regarding the past as well as to name the main agents influencing the formation and interpretation that they offer (Johnson 1995). The objects of interest are usually memorials honored at the local and national levels, such as monuments in honor of military victories, memorial cemeteries, monuments connected with the history of national catastrophes such as the Holocaust and other genocides. Interest in military memorials or monuments dedicated to the Holocaust stems from the significance of the historical trauma for memory studies in general (Alexander 2002). Therefore, from the whole list of memorials, explicitly "traumatic places" or places where mass death occurred grab the attention of researchers (Assmann 2014:246). The study of Russian and Soviet memory has taken place in the same way (Ryleva and Konradova 2005; Bogumił 2010; Danilova 2015; Gabovich 2015).

Without denying the approach suggested by historians of memory, cultural geographers view the memorials from a somewhat different angle. For them, the location of the memorial is significant. As Brian S. Osborne writes:

"place" is an emotive entity, experienced emotionally and defined subjectively. That is, people produce places and they also derive their identities from them. Farms and fields, streets and neighborhoods, vernacular buildings and institutional edifices, parks and monuments, songs and stories: all are expressions of the social activities in space that transform the latter into place. They are the spatial co-ordinates for identity and belonging in the reciprocal relationship between people and the places they inhabit. (2006:149)

By focusing on a memorial's location, cultural geographers therefore avoid the determinism sometimes inherent in memory studies by historians who directly link the installation of the monument with ideology and do not take into account the location of the installation and the cultural connotations associated with it. For researchers working in cultural geography, on the contrary, it is important to include or exclude the 
memorial from the general cultural landscape of the area. They are interested in the interaction of the monument with the population and other objects, understanding its place in the design of imagined communities (Mitchell 2003). As Nuala Johnson writes in her study: "an examination of public statues enables the researcher to gain some insights into how the public imagination is aroused and developed in the context of the ongoing task of nation-building. Statues, as part of the cityscape or rural landscape, act not only as concentrated nodes but also as circuits of memory where individual elements can be jettisoned from popular consciousness" (1995:63).

Historians of memory and cultural geographers are not the only ones who consider monumental art a source of knowledge about the relationship between authority and society. Historians of culture also provide tools and optics for analysis. In the field of Soviet architecture, Vladimir Paperny has written about the interaction of these fields. Relying on the analysis of architectural styles and projects of the pre-war USSR, he shares two opposing and succeeding frameworks, calling them Culture One and Culture Two. He argues that Culture One is characterized by "horizontality," which means that "the values of the periphery become more important than those of the center.... In this phase, the authorities are not concerned with architecture, or are concerned with it only to a minimal degree.... Culture Two is characterized by the transfer of values to the center. Society ossifies and crystallizes. The authorities start an interest in architecture both as a practical means for securing the population and as the spatial expression of a new center-based system of values" (Paperny 2002:xxiv).

Paperny's observations regarding Soviet architecture are relevant for how we describe postwar Soviet memorial complexes. Magnificent monuments and steles that rose above the streets and squares of Leningrad in the years of Culture Two (during the time of Joseph Stalin and Leonid Brezhnev) were not only tributes to memory and glory but also symbols of power. These are attributes of pride, grandeur, and active efforts to shape the country's cultural memory. During Culture One (the time of Nikita Khrushchev's "Thaw" and Mikhail Gorbachev's perestroika), small memorials were recreated or restored, away from the center of the city, and were transferred to the care of Leningrad's local communities or labor collectives. Such are the memorials from the project Green Belt of Glory. ${ }^{5}$ The authorities "give" the possibility to commemorate WWII and the Siege of Leningrad in a public space to those who need it-for instance, to veterans and witnesses. To borrow a term from Aleida Assmann, we could call this a "social" or generational memory (2014:24-25). It was through the interactions between Culture One and Culture Two, which replaced each other throughout the twentieth century, that the norms and rules for narrating the culture of memory were formed.

Let us look at the cultural landscape of the city of Leningrad/Saint Petersburg. What stories do its monuments and memorials tell? How has the urban landscape changed in connection with the political changes during and after perestroika and with the emergence of new memory actors?

${ }^{5}$ The Green Belt of Glory is a complex of memorials located on the outskirts of Saint Petersburg and commemorating battles and other military events of the Second World War. 


\section{URBAN LANDSCAPES OF SOCIALIST REALISM: SOVIET MEMORIAL COMPLEXES ABOUT THE SIEGE OF LENINGRAD}

\section{PISKAREVSKOE MEMORIAL CEMETERY}

The Soviet museum and memorial complexes dedicated to the Leningrad blockade reflected official ideas about this event and were created in the aesthetics of socialist realism. Monument and memorial projects were financed and developed through the system of state institutions. The Piskarevskoe Memorial Cemetery (built in 1960), the Green Belt of Glory (1965-1968), and the Monument to the Heroic Defenders of Leningrad (1975) are the most significant memorial complexes commemorating the blockade created in the Soviet years.

The construction of memorial complexes was a feature of the postwar process of commemorating military events in the USSR (Ryleva and Konradova 2005). Such complexes included various pictorial elements and combined sculptural and architectural solutions that affected the feelings and emotions of visitors to the memorial. Although the sculptural and architectural projects dedicated to the blockade were created with strict hierarchy of meanings and themes, this did not prevent them from accentuating different aspects of the blockade's history.

The Piskarevskoe Memorial Cemetery project, developed by a group of Leningrad sculptors and architects led by Aleksandr Vasil'ev and Evgenii Levinson, emphasized the connection between the revolutionary past of Petrograd and the defense of besieged Leningrad. Many of the choices made for the Piskarevskoe memorial complex bore elements of the monument to the heroes of the revolution on the Field of Mars ${ }^{6}$ (Rusinova 2006:339). Moreover, the eternal flame at Piskarevskoe Cemetery was delivered in 1960 from the Field of Mars. Linking Piskarevskoe Cemetery with the Field of Mars, the authors of the project expressed an important idea that was also articulated in the military and postwar official discourse on the blockade: a strong connection between the courage of the defenders of Leningrad during WWII and the heroism of the Petrograd revolutionaries. These are the phenomena of one symbolic series. The authors declared that the origins of blockade heroism should be sought in the sacred-for the Soviet patriot-revolutionary past of the country.

It is significant that the stylistics of the Piskarevskoe Memorial Cemetery influenced the memorial ensemble of the much less famous city memorial at the Serafimovskoe Cemetery, built in 1958-1965 under the guidance of architect Iakov Lukin and sculptor Robert Taurit. That memorial opened on January 27, 1965, at the site of mass graves of the blockade. Lukin and Taurit's project included a stele with four through-openings. Five pylons of the stele have the figures of a sailor, elderly and young workers, a woman, and a soldier. The memorial also had an eternal flame (Poretskina 1985).

${ }^{6}$ The Field of Mars, or Marsovo Pole, is a green recreation zone in the center of Saint Petersburg. During the Soviet era it was one of the most significant places of memory of the Russian Revolution. In the center of the park is a memorial to workers and soldiers killed during both the February and October revolutions of 1917. 
The memorial complexes of Piskarevskoe and Serafimovskoe cemeteries should be interpreted - in the terminology of Aleida Assmann - as "traumatic sites of memory" (2014:241). According to her, these could be cemeteries, mass graves, or death camps. A distinctive feature of these places, in Assmann's opinion, is "Antaeus magic," which acts through the authenticity of the place. People expect a special emotional impact from visiting such places (243). Both of these cemeteries were places of mass burials during the siege. For architects and visitors, this fact has been very important. For instance, there are 186 mass graves in the Piskarevskoe Cemetery in which are buried 420,000 civilians and 70,000 soldiers. ${ }^{7}$ Therefore, even though the main compositional focus of both memorials has shifted to the military victories and the courage and steadfastness of the defenders of Leningrad, the function of the cemetery as a place of mourning and sorrow has not disappeared (Kaspe 2018).

\section{THE GREEN BELT OF GLORY AND THE MONUMENT TO THE HEROIC DEFENDERS OF LENINGRAD}

This principle of a place's authenticity was important for another memorial complex dedicated to the Siege of Leningrad, the Green Belt of Glory. This project was developed between 1958 and 1964 in the architectural and planning department of the Leningrad City Executive Committee and the workshop of the Lenproekt Institute under architects Gennadii Buldakov, Vladislav Gaikovich, and Marianna Sementovskaia. The complex was dedicated to the military glory of the defenders of Leningrad. The line of defense closest to the city was recreated, visually reproduced in the Leningrad suburbs through commemorative signs, memorials, preserved or restored defensive structures, and green spaces. The plan was to install more than 80 monuments, obelisks, and other memorial structures in total (Luk'ianov 1985). The total length of the memorial exceeded 200 kilometers. The first stage of the memorial complex was completed in 1967; the second stage was completed by the thirtieth anniversary of the WWII victory in 1975.

Bloody battles near Leningrad, which provided the basis for this commemorative memorial, were combined with stories from the city's civilian population. Thus, the monument The Broken Ring (1966) referred to the evacuation of residents and was installed at the beginning of the Road of Life. ${ }^{8}$ The Flower of Life monument (1968) was erected in memory of the schoolchildren of Leningrad. But most of the monuments in the Green Belt of Glory focused on military history or were dedicated to important events from the frontlines.

The concept of the memorial complex recreating the city's wartime line of defense was not unique to Leningrad. Following the one in Leningrad, a Belt of Glory was constructed in Odessa in 1964-1967. It also maintained the line of defense of the city. Twelve battlefields of monuments, like the ones near Leningrad, marked the most significant events of military defense. Obviously, this way of commemorating

\footnotetext{
${ }^{7}$ Information from the official website of the Piskarevskoe Memorial Cemetery (http://www. pmemorial.ru/blockade/history).

${ }^{8}$ The Road of Life was the winter transport route across the frozen Lake Ladoga, which provided the only access to the besieged city of Leningrad.
} 
events seemed to architects universally applicable to all cities where the line of defense was clearly delineated.

The Green Belt of Glory did not look like Piskarevskoe Memorial Cemetery, nor was it conceived as a rival to it. All of its facilities were located outside the city, which made it difficult to include its monuments in the official rituals celebrating Victory Day. Because of the distance between the city and the settlements on its outskirts, the memorials of this complex looked very isolated and not well connected with each other. This effect was exacerbated by the very narrow "specialized" monuments that marked places of battle or significant events in the defense. At the same time, a visitor could choose their "own" monument for reverence according to their aesthetic preferences and ideas about the past. As a result, the memorial complex willingly or unwillingly promoted variations in the official story of the blockade and in some cases encouraged growing self-awareness among certain groups of visitors. For example, the first society of the siege survivors appeared as a result of a meeting of former Leningrad schoolchildren at the Flower of Life monument on May 9, 1968 (Voronina 2012). Although all memorials of the Green Belt of Glory were dedicated to the glory of the Soviet army and the victory over its enemies, the appearance and remoteness of some of them from the city center made them seem less formalized. Some monuments were erected using money raised by trade unions and Leningrad organizations and industries. According to Ol'ga Rusinova, the monument the Broken Ring (by architect Vladimir Filippov and sculptor Konstantin Simun) "was appreciated by the townspeople as an alternative to [state] monuments" (2006:345).

Despite sharing the ideological message of all other blockade monuments, which perpetuated the memory of the hero-victors, the Green Belt of Glory, strongly contrasted with the Piskarevskoe Memorial Cemetery and the Monument to the Heroic Defenders of Leningrad in its architectural concept. In Paperny's terms ([1985] 1996), the "horizontal" direction of the Green Belt of Glory manifested itself in the periphery of those monuments, which towered on the most prestigious and significant areas of the city. In this sense, the authenticity of the place played an important role. Furthermore, people from the city's industries and trade unions took patronage over the monuments of the Green Belt of Glory, and therefore responsibility for the monuments' erection and care for them seemed to be transferred away from the central authorities and became a public-and almost voluntary-matter (Luk'ianov 1985).

By contrast, the construction of the Monument to the Heroic Defenders of Leningrad on Victory Square in Moskovskii District embodied the return of the "vertical," of Culture One. The memorial was dominated by monumental bronze sculptures, magnificent designs, and upward stately steles. The Monument to the Heroic Defenders of Leningrad was conceived as a symbolic center and the antithesis of the Green Belt of Glory memorials. It was a triumph of Soviet grand architecture. It was created by a group of architects led by Sergei Speranskii, Valentin Kamenskii, and sculptor Mikhail Anikushin, and it opened on May 9, 1975, on Victory Square at the entrance to Moskovskii Prospekt, the main thoroughfare of Soviet Leningrad. The complex was a sculptural composition consisting of bronze figures of soldiers and workers. At the 
center of them stood a stele 48 meters high. The memorial is located at the southern entrance to the city from the Moscow Highway and Pulkovo Airport. The monument was to become the calling card of the socialist city, introducing tourists and others visitors to Leningrad for the first time to its greatness and heroism during the Second World War and alerting them to the place of the Leningrad blockade in the city space, which was permeated with the construction of local and Soviet identity.

The Monument to the Heroic Defenders is the first monument whose location was chosen outside the "traumatic place." It is situated on the second line of defense. It was neither a place of mass graves nor a place of fierce fighting, but it perfectly complemented the magnificent decoration of Stalinist neoclassicism, which became the main style of Moskovskii Prospekt. Victory Park, built on the site of the blockade-era crematorium, was also located on Moskovskii Prospekt, but it did not become an alternative place for the monument. Authenticity of place, therefore, was sacrificed to functionality, which probably influenced the very disdainful attitude to this memorial in the city: a stele, which took the form of a woodworking tool, was nicknamed "the chisel" by city residents.

The described memorial complexes of the Soviet era have become integral parts of the urban and suburban landscape of Leningrad/Saint Petersburg. Although they consistently presented the blockade as a heroic page in the history of the city and the Second World War, drawing visitors' attention to the valor and courage of the defenders of the "stronghold on the Neva," the specific forms of memorials, as well as styles and sizes and monuments, changed over time. This specificity, according to Paperny, depended on the degree of involvement and interest from the political authorities in the commemoration of the past: the greater their interest, the larger the sculptural compositions and the higher the stele. However, in his opinion, this interest has never been durable and has become rather indifferent over time (Paperny [1985] 1996:21). During these periods, the initiative to install monuments passed to actors who were more interested in the past.

The memory of the blockade was thus associated with both local and Soviet identities. On the one hand, the breakthrough and lifting of the blockade in official Soviet discourse was always interpreted as one of the great victories of Soviet weapons in World War II. It is not surprising that in 1945 Leningrad, with Stalingrad, Sevastopol, and Odessa, received the status of "Hero City." On the other hand, the blockade was an important event for local identity. Writer Daniil Granin emphasized Leningraders' love of freedom, which he directly connected with the prerevolutionary Petersburg intelligentsia. He wrote: "The heroism of the Leningrad blockade was perceived by Stalin's entourage as a manifestation of the freedom-loving spirit, the rebelliousness of the city, its excessive and even threatening self-state" (Adamovich and Granin [1979] 1994:375). So the heroism of the inhabitants and defenders of Leningrad was a common discursive ground of all Soviet monuments about the siege.

Unlike street sculptures that often could not be easily noticed by passersby, the memorial complexes counted on visitors being consciously involved in the symbolic system of the monument. The feelings of pride, gratitude, and sorrow were experi- 
enced by Soviet people visiting Piskarevskoe Memorial Cemetery, the Monument to the Heroic Defenders of Leningrad, or the memorials of the Green Belt of Glory.

The image of the siege represented in the city's memorial complexes primarily reflected the military memory of the event, emphasizing the heroism and courage of soldiers who fought on the approaches to Leningrad. The city's civilian population, by contrast, was given less importance. For a long time the number of starved civilians in Leningrad was deliberately underestimated. Until the end of the Soviet period the official number of deaths in Leningrad was about 600,000 people (Voronina 2011). This corresponded to the ideas of heroism that existed in Soviet times. In the USSR the heroism of Leningrad was primarily associated with military operations and not with starvation, so the topic of mass death from hunger was never a special theme of the commemoration. The heroic defense overshadowed the siege as catastrophe. Mass starvation was interpreted only as a consequence of the manifested heroism.

\section{LATE SOVIET AND POST-SOVIET MEMORY OF THE SIEGE: NEW ACTORS OF MEMORY}

In the 1980s Michael Gorbachev believed that a policy of openness (glasnost) would alleviate tensions and mistrust in Soviet society as well as restore respect for Soviet socialism. However, glasnost had the opposite effect. Open discussion of the Soviet past did not lend legitimacy to the reformers of the Soviet regime. Instead, it deprived them of societal support. The past became a dangerous weapon, which different social groups wielded in pursuit of their own political ends. Some groups appealed to the past in order to make territorial claims against their neighbors. Other communities fought for benefits and compensation based on interpretations of the past. Societies of victims of political repressions and of the blockade survivors were established. These groups tried to use the past to claim benefits and entitlements. In short, different actors tried to use the past (that is, to create a version of the past) in pursuit of their own aims, some of them rather successfully.

The complex attitude towards the Soviet past that immediately arrived with perestroika explicitly raised questions about the fate of Soviet monuments. Researchers Benjamin Forest and Juliet Johnson (2002) wrote about three different scenarios that existed for the memorials on the eve of perestroika: co-option/glorification, disavowal, or contestation. Co-opted/glorified memorials are maintained or exulted further. As argued by Forest and Johnson, in the case of military memorials, as a rule, it was a matter of glorification, since the memory of the war in the years of perestroika became the most important component of Russian identity. Analyzing the memorials on Poklonnaia Hill in Moscow, the authors wrote:

In the transition from Soviet to Russian nationalism, for example, the style and design of official monuments reflected much continuity between Russia and the USSR. Although the bulk of Victory Park [on Poklonnaia Hill in Moscow] was built after the fall of the Soviet Union, the memorial replicates the gigantic scale and overt symbolism characteristic of Soviet memorials. The story of post-Soviet 
Russian identity is, however, a complex one; Russians have not simply reproduced Soviet imagery. The addition of religious sites at Victory Park, for example, was not envisioned by its nominally atheist Soviet-era architects. In other cases, the meaning of Soviet monuments, memorials, and museums has been significantly altered by changing the composition of the sites or by moving monuments to different locations. (Forest and Johnson 2002:525)

The historical symbolism of Leningrad became a powerful rallying point among those who favored perestroika, because they saw Leningrad as a stronghold of independence and democracy. The city was not just the "cradle of the revolution" but also the "cradle of Russian democracy." Russian reformers of the 1990s believed that Leningrad's wartime authorities had pursued politics that were independent from the Kremlin, that Leningrad had always (even in Soviet times) had more potential for democracy than other places in the country, and that the siege had been a time of independence for the city (Sobchak 1999). For the opponents of perestroika the blockade was also important as it served as evidence of the strength and power of the Soviet state and of the advantages of the communist system. Therefore, they saw their task in protecting the image of the blockade created in the USSR from any changes. With this purpose, in 1992 the Association of Historians Studying the Heroic Defense of Leningrad and the Siege was established. As one of the most famous Soviet historians of the blockade, Andrei Dzeniskevich, wrote: "Freedom of expression turned into a 'regime of glasnost,' which did not seek for new methods in historiography but searched for more and more new ways (and occasions) to mud the entire past history of the Soviet Union and Russia. This was done in order to justify the destruction of the great state" (1998:54). All of them recognized the Siege of Leningrad as a very important event that could be used in arguments for any ideological construction (Kelly 2011). In both cases, the image of the people from Leningrad was always based on a positive view of the population's heroism. This identity had great symbolic value in political life. Moreover, this interpretation also led most local political leaders to ignore the nonheroic, even criminal acts committed by some blokadniki as well as the mistakes made by the Leningrad city authorities during the siege.

Although the last word in decisions about installations of memorials remained with city authorities, the initiative now often came from different social and civic groups. Not only the process of creating monuments changed, but also the character of the monuments themselves. Urban sculptures became most common form of siege commemoration in Saint Petersburg. In 2002, on the initiative of veterans of the local air defense, a monument to the women of the city's antiaircraft defense was erected on Kronverskaia Street. The authors of the project were sculptor Lev Smorgon and architect Igor' Matveev. That same year the monument Blockade Polynya was built on the embankment of the Fontanka River. It depicts a woman fetching water from the river. A plaque commemorating the wartime PA system-and called the Blockade Loudspeaker-was mounted on Nevskii Prospekt in 2002. The architect was Anatolii Chernov. In 2005 sculptor N. Chepurnoi created the commemorative plaque Blockade Stickleback in Kronshtadt near Saint Petersburg. 
The sculptures dedicated to the blockade during and after perestroika lacked military pathos. This was a sign of the change in the public understandings of the blockade. At this time the blockade was associated primarily with the difficult living conditions imposed upon the civilian population. At the same time, the heroism of the residents remained a defining theme in the memory of the siege during those years. The feat of the civilian population was associated with the routines of life in the besieged city. This heroism was apparent in city sculptures, whose small size made the monuments almost imperceptible to most living in the city but very important and significant for the group that established the symbol. ${ }^{9}$

The Russian Orthodox Church also joined this struggle over historical memory. After perestroika began the Moscow Patriarchate of the ROC began popularizing its own versions of the Soviet past. The 1,000th anniversary of the adoption of Christianity in Rus' in 1988 and the process of reunification of the Russian Orthodox Church with the Russian Orthodox Church Abroad sparked this. One of the most important stipulations of unification was the condemnation of Soviet repressions and persecutions of the Orthodox Church. The ROC thus developed its own interpretation of Soviet history. On one hand, this was a story of the church's persecution; on the other hand, the ROC underlined the Soviet state's huge success in industrial and economic development, which guided the development of modern Russia, where it hoped to play a major role. In this way, Russian nationalism was integral to many Russian Orthodox bishops' and priests' historical imaginations (Mitrofanova 2016).

Analyzing the ROC at the turn of the century, the historian Nikolai Mitrokhin concluded that in the 2000s the church played a decorative role in the political and ideological life of Russia (2004:267). Gradually it has become more significant. The key issue in Soviet history that attracted church leaders during those years was not the history of World War II but the history of Soviet repressions and persecutions of the church during the 1917 Revolution and Great Terror (Bogumił 2010). The blockade hardly ever figured into these discussions. For this reason, in the 1990s and beginning of 2000s, those who created the "places of memory," the churches honoring WWII, typically were not clergy.

Thus, additional actors began using the memory of the blockade in their political struggles or to strengthen their position in various fields of cultural production. They pursued different goals, but most of their constructions proceeded from the Soviet understanding of the blockade as a heroic event.

Therefore, the actors using the memory of the blockade had little reason to rethink that memory during perestroika. There were slight changes in the details. For instance, before perestroika Leningrad authorities were praised for their organized and altruistic work for the country. Since perestroika, the city authorities were praised for defending local interests and opposing Stalin. Before perestroika, the heroes of the blockade were those who could "prove" their heroic feats: soldiers and workers and others engaged in socially significant events. Since perestroika, the he-

${ }_{9}^{9}$ Mikhail Zolotonosov, “Blokada imeet mnogo gitik. "Gorod 812: Peterburgskii zhurnal, July 15, 2018. Retrieved November 8, 2018 (http://gorod-812.ru/skandal-vokrug-konkursa-na-proektpamyatnika-uchitelyu-blokadnogo-leningrada/). 
roes included all those who experienced the horrors of the blockade, signaling how heroism became a moral category rather than a measure of how much one served the state and community.

\section{"THE BLOCKADE TEMPLES": NATIONALISTS AND THE SIEGE}

In 1996 the Church of the Assumption of the Blessed Virgin Mary was built in Malookhtinskoe Cemetery in the northeastern part of the city on the initiative of the famous Saint Petersburg restorer Valentin Kovalevskii. At the same time, Kovalevskii was busy setting up a nationalist political party, the Party for the Orthodox Revival, which advocated the restoration of monarchy, Orthodoxy as mandatory religion, and an estate-based or socially hierarchical society. ${ }^{10}$ Having received the support of the Metropolitan Ioann (Snychev) of Saint Petersburg and Ladoga, who was known for his conservative, nationalistic views, Kovalevskii established a working group and launched a fundraising campaign for the construction of the church in 1994.

Support from the diocesan leadership for Kovalevskii's initiative and the Malookhtinskoe Cemetery church did not stem from the desire that the ROC join in the struggle over the memory of the siege and World War II. Rather, it reflected a desire to install another urban church in a dynamically developing district of the city. The history of the Siege of Leningrad thus did not play a special significance for the Russian Orthodox Church as it did for Kovalevskii.

From the very beginning the project's initiators stressed the special status of the temple under construction; it was meant to embody the new Orthodox memory of the siege. The choice of the construction site clearly showed a connection to the blockade: Malookhtinskoe Cemetery was shut down in the 1930s but used for mass burials during the siege. Additionally, the fundraising campaign was conducted quite resourcefully. People whose relatives died of hunger in the city or at the Leningrad Front were invited to buy bricks for the future church from the contractor and inscribe the names of their deceased relatives on them. The campaign was actively promoted by the mass media in Saint Petersburg. It is hard to assess how popular it was among the city's population, but on the website of the Church of the Assumption of the Blessed Virgin Mary on Malaia Okhta (which almost instantly became known as the Blockade Temple), thousands of such donations are mentioned. ${ }^{11}$ A newly established prayer book in the church catalogued the names of those who died during the siege and thus became another binding element for the "blockade memory of the city."

Feliks Romanovskii and Iurii Gruzdev from Lenproektstroi were the project's architects. Construction lasted from 1996 until 1999. During this time, a temporary wooden chapel, which eventually housed the Church of Saint Maria Magdalene, was erected on the site and named after a church that was destroyed in the 1930s. Later,

${ }^{10}$ For the program and history of this party see its website (http://www.partia-pv.ru/).

${ }^{11}$ See the official website of the Church of the Assumption of the Blessed Virgin Mary on Malaia Okhta (http://moyhram.org/history/). 
a bell tower was erected near the church as well as several monuments dedicated to some events of the Russia's past. For instance, on June 22, 2003, the anniversary of Germany's invasion of the USSR, Metropolitan of Saint Petersburg and Ladoga Vladimir blessed one monument-an angel with a cross on top of a granite rock, dedicated to the Russian Orthodox warriors who died in the Caucasus during the Soviet period. On August 28, 2007, another monument was inaugurated, the work of the sculptor Viktor Shuvalov, dedicated to the children-victims of the Chechen terrorist act in Beslan (North Ossetia). ${ }^{12} \mathrm{~A}$ monument was also built and dedicated to the martyred Metropolitan of Petrograd Ven'iamin (Kazanskii), who was executed by the authorities in 1922 and canonized in 1992. Thus, the structures in Malaia Okhta near the church serve as examples of how the ROC memorialized the past, including recent events.

Officially, the decision to erect the church in Malaia 0khta was approved by the city's architectural department and did not represent the city governor's official point of view. At the same time, it would be naive to think that the city's leaders were not informed of the ROC's plans to build a new church. Most likely they agreed to this way of immortalizing the memory of the siege, as it corresponded to their ideological preferences. Mayor Anatolii Sobchak, head of Saint Petersburg until 1996, as well as his successor, Governor Vladimir Iakovlev, perceived the communists to be bigger threats to their position and to their reforms than the nationalists who promoted Orthodoxy. In this regard, the policy of returning historical names to the city was the most visible part of the struggle of the city government with the Communist Party in the period of the 1990s. The renaming of Leningrad to Saint Petersburg took place on September 8, 1991, and it represented Sobchak's victory over the communist opposition. As a result, the project of a new church also managed to get all necessary approvals from the city's architectural committees.

After its sanctification on September 8, 2001, the sixtieth anniversary of the siege's beginning, the church had functioned in a normal way; little else linked the temple to the blockade. An exception was that on Victory Day or the blockade anniversaries (of the beginning, breaking, and lifting of the siege) funeral prayer services are held in the church. Judging from the church's website, which describes the parish's activities in detail, the siege is not mentioned anywhere-neither in the prayers, nor in its bulletin, The Blockade Temple. ${ }^{13}$ Such ambivalence, given that the church was called The Blockade Temple but downplayed this theme, led to confusion as to how one should regard the church. Were these references to the siege just a successful marketing trick that the project's organizers used to attract public attention and funds? Or was this an attempt to interpret the history of the siege? What did the

${ }^{12}$ On September 1, 2004, armed Chechen rebels took approximately 1,200 children and adults hostage at a school in Beslan, Republic of North Ossetia in southern Russia. The standoff ended after two days, with more than 330 killed, including 186 children, and more than 700 people wounded.

${ }^{13}$ The Blockade Temple is the name of the website of the Church of the Assumption of the Blessed Virgin Mary on Malaia Okhta. 
church symbolize and what meaning did it try to convey? What kind of story did it proclaim to tell?

There is no single way to interpret the church in Malaia Okhta. On the church's website, parishioners' interpretations of the siege signal ambivalence. Essays are posted to the web page relaying the history of the church's construction. An essay by the Saint Petersburg ethnographer Iurii Piriutko explains that the fact that the church was constructed without the help of the city authorities was deeply symbolic: "the city authorities did not take part in building this church; it was built as a symbol of public respect to the memory of the dead, as a sign of the people's love." 14 It was important for the author to accentuate the new memorial's independence from the city authorities' compromised reputation regarding the siege. This view was undoubtedly an abrupt change in the presentation of the city's memory of the siege. Up to that point, there seemed to be a positive attitude toward Leningrad's Communist Party leaders during the siege. One of the most prominent and influential Leningrad writers of that times, the author of the famous A Book of the Blockade, Daniil Granin created a heroic image of the city's Soviet leaders (Adamovich and Granin [1979] 1994). This kind of image dominated secular presentations of the siege through the 1990s. The Orthodox bishops regarded the Bolsheviks as persecutors of religion. At the same time, the clergy's often-nationalistic views fostered a symbiosis with ideas about the Soviet past. For example, Party leaders were not demonized when it came to WWII, but with respect to other periods of the Soviet era, Metropolitan Ioann (Snychev) described the leaders of the USSR as apostates, where some of them were the incarnation of evil and wished harm to the people of Russia and devastation to the country, while others did evil unconsciously because they were "trustful and well-intentioned Russian communists, who simply believed in all proclaimed slogans. They zealously and ingeniously longed for constructive work, sincerely hoping to build a world of total brotherhood, described by 'the one and only right' doctrine" (Snychev 1996). Therefore, everything good that existed in the USSR was achieved by Russian communists who advocated for national interests. According to Snychev, all that was evil emerged from the fraction of Jews and other foreigners who were the real enemies of the Russian people. Leningrad's wartime Party boss Andrei Zhdanov was evaluated by Snychev as a positive figure who defended the interests of the Russians not so much during the siege but rather after it when he launched the ruthless "anticosmopolitan" campaign against Jews, foreigners, and intellectuals. This assertion allowed Snychev to classify Zhdanov as a patriot. Thus, despite the fact that the Russian Orthodox Church officially criticized Soviet leadership, the clergy approved of its patriotic aspirations, especially when connected to the siege and the war. Evidently, this is the reason why the ROC never expressed a negative view of Leningrad's wartime authorities. Piriutko's article was published next to others, much more supportive of the city leaders of those times.

${ }^{14}$ Iurii Piriutko, "Istoriia khrama." Website of the Church of the Assumption of the Blessed Virgin Mary on Malaia Okhta (http://moyhram.org/history). 
Elena Isakova, a representative of the monuments protection committee, expressed a viewpoint that was much closer to the Soviet interpretation of the siege as a heroic event. In an article, Isakova pointed to the architectural and historical tradition of commemorating the Russian military victories by creation of churches. She wrote:

And the meaning of the creation of the Blockade Temple is the same, exactly corresponding to the ancient tradition. People, who died during the siege, died from hunger, cold, bombings and gunfire, defending this city-died for all of us, for our native country. And it does not matter if they died from gunfire or hunger-it is an act of bravery. They did not let the enemy into the city, did not allow the fascists to destroy the city, the people, our faith. And they are worthy of this memorial, of this church. ${ }^{15}$

According to the author, people who died during the siege were heroes and therefore deserved their own church. However, this article claimed that unlike other Soviet heroes, the besieged population also defended "our faith." The author's idea is clear: the people's patriotism allowed them to save the city, and, therefore, they deserve a religious tribute. The priest Andrei Pankov developed this idea in his story about the circumstances of the church's appearance: "The country was undergoing a difficult period of demolishing the Soviet way of life. Blindly following the 'Western democratic values' turned many of the facts that had been considered acts of bravery of the Soviet people into some kind of joke. The time went by. The memory of the hundred thousands who died during the siege was slowly forgotten by the new generations. The decision to build this church, this memorial was made so that we remember the facts that we should not forget." ${ }^{16}$ For him the erection of this church represents one of the "symbols of renaissance of our people, our faith, conscience, and pursuit of God," which do not seem to go along with Western democratic values, according to the text. Although the author of this history of the church's creation was not very eloquent, his thesis was very close to the ideas of the main sponsor and guardian of the church, Kovalevskii. Kovalevskii regarded the Russian Orthodox Church as a guarantor of the Russian nation. For him, the construction of the church was a patriotic act. Therefore, like other Saint Petersburg memorials of the siege, the Blockade Temple not only commemorated the victims but also was a memorial to heroism.

Considering how important the memory of the siege is for the Saint Petersburg public, one can assume that the invocation of the besieged people's heroism resonated with the population. In this context, the construction of the church was an important informational pretext for the supporters of the nationalist-patriotic wing of the Russian politics in the 1990s to declare themselves, their party, and their po-

${ }^{15}$ Elena Isakova, "V rusle traditsii." Website of the Church of the Assumption of the Blessed Virgin Mary on Malaia Okhta (http://moyhram.org/history).

${ }^{16}$ Andrei Pankov, "Torzhestvo istoricheskoi spravedlivosti." Website of the Church of the Assumption of the Blessed Virgin Mary on Malaia Okhta (http://moyhram.org/history). 
litical and religious beliefs and ambitions. As a result, the history of the siege was used as the basis for Russian Orthodox nationalists to claim that the people under siege were deeply religious and that they suffered and sacrificed in the name of their country and their faith.

The secular history of the siege from the Soviet period was easily connected to this religious conceptualization. It is notable that it did not require conceptual reassessment of the memory of the siege, present in the city at that time. The heroism, sacrifice, and bravery of the population were common clues to understanding the siege both in the Russian Orthodox tradition and in secular official politics. The siege was and is a means of patriotic education. Painful questions about the real history of the siege lay beyond these presentations. The trauma of the city blockade was once again disguised by the glossy heroic interpretations, this time in Russian Orthodox terms. It is also not surprising that the Siege of Leningrad was represented as a main regional topic in the Saint Petersburg's version of the multimedia exhibition Russia Is My History in Saint Petersburg. This exhibition is a new ideological manifestation of Russian authority. It was conceptualized by the ROC bishop Tikhon (Shchevkunov) and received financial support from the Russian government. Today the exhibition Russia Is My History can be seen in 15 of Russia's biggest cities. ${ }^{17}$

\section{VICTORY PARK'S BLOCKADE TEMPLE: FROM RECREATIONAL FACILITY TO A PLACE OF MEMORY}

The Church of all Saints Resplendent in the Russian Land was another religious site dedicated to the Siege of Leningrad. It is located in the southwestern part of the city, in Moskovskii District of Saint Petersburg. This explains why it is called the Moscow Victory Park. The church was built and sanctified in 2010. The opening was timed with the sixty-fifth anniversary of the victory in the Second World War.

As in the case of the construction of the Church of the Assumption of the Blessed Virgin Mary on Malaia Okhta, the history of this monument eloquently tells us about the roots of the church discourse on the siege, as well as about the processes in Russian society that fostered its proliferation.

The idea of creating an Orthodox memorial to memorialize those who died during the siege emerged among civic activists soon after it was publicly announced that in 1942 there had been a crematorium on the territory, housed in a former brick factory. After the war, the Moskovskii District Victory Park was built on the site. The local press told readers that hundreds of the city's inhabitants were cremated there during the war and their remains buried not far from this place. The park comprised 68 hectares of land and was situated between Basseinaia and Kuznetsovskaia Streets. In Soviet times, the Moskovskii District Victory Park memorialized the war but not the siege specifically. This was stressed in the park's dedication, during which there was no mention that Leningraders were cremated and buried there during the siege. On the contrary, the architects of the project, Valerian Kirkhoglani and Evgenii Kato-

${ }^{17}$ See the exhibition's website: https://myhistorypark.ru/. 
nin, tried to underscore the glory of victory using official Soviet discourse. The Alley of Heroes, which stretches from the main entrance and through the central axis of the park, was decorated with monuments to those who had twice been awarded the order Hero of the Soviet Union and were born in Leningrad. Until 1985 this alley was gradually supplemented by new monuments to scientists, workers, and engineers who became so-called double holders of this award after the war. The alley's end was crowned by a monument to Stalin, which was removed during the Thaw period. Later, in 1995, a monument was erected to Marshall Georgii Zhukov, the most famous Soviet general of WWII. From the fountain at the main entrance two other alleys radiated out. They were adorned by bronze monuments to the most significant heroes of the Great Patriotic War: Zoia Kosmodem'ianskaia (built in 1951, by sculptor Matvei Manizer) and Aleksandr Matrosov (built in 1952, by sculptor Leonid Eidlin). In 1953 the main entrance was decorated by two propylaea with six bronze bas-reliefs dedicated to courage displayed at the front and in the rear. Flanking the central alley were picturesque landscapes reminiscent of English gardens planted in the early nineteenth century. Therefore, the park initially was planned not only as a memorial but as a recreational place. ${ }^{18}$ In 1961 the Victory Park metro station opened near the park.

Victory Park's historical significance was reconsidered during perestroika. In November 1989 journalist Anna Repina published an article in the Leningrad newspaper Smena about the history of the siege crematorium. ${ }^{19}$ Repina interviewed former workers from the crematorium, who described the places of mass burials among the ruins of the brick factory where Victory Park was built. So its history became public knowledge.

Almost immediately after that, the authorities from Leningrad's Moskovskii District decided to set up a memorial zone in Victory Park dedicated to the siege. The project was initiated by a society of siege veterans from the district, which was very active in the city at the time. The architect, Kirkhoglani, already worked at the park and was made the head of the project. The project entailed the creation of a special memorial zone in the park and an alley near Victory Street that would honor the victims of the siege. The reconstruction project was approved but never realized.

This struggle for control over the memory of the siege became manifest in the reconstruction of Victory Park. Initially the authorities eagerly cooperated with the associations of the siege survivors. In 1995, on the initiative of the Moscow District's branch of the Inhabitants of Besieged Leningrad, along with that district's local authorities, the first memorial-the Pavilion of Memory by the architect Elena Shapovalova-was built. The memorial is a rotunda marked with the inscription: "In the memory of the thousands who died as victims of the siege and as defenders of the city and who were cremated in the ovens of the former brick factory."

Around the same time a Russian Orthodox community emerged around Victory Park. It proposed building a church to commemorate the people buried there. In

${ }^{18}$ Vitalii Minchenko, “Moskovskii Park Pobedy." Subscribe.ru, January 20, 2006. Retrieved November 8, 2018 (https://subscribe.ru/archive/country.spb.spburg/200601/31074840.html/).

${ }^{19}$ Anna Repina, “Pepel, kotoryi ne stuchit v nashi serdtsa." Smena, November 14, 1989, p. 2. 
1996, without any agreement from the city authorities, it installed a worship cross and started to hold public services on days associated with the siege. It is noteworthy that this initiative existed in tandem with the activities of veterans' groups, who envisioned a memorial zone, not a new church, for the park.

Meanwhile, the veterans' association insisted that the reconstruction of this area of Victory Park be reassessed in hopes of creating a memorial zone honoring the victims of the siege. The government's resolution on this was signed on April 4, 1996. It permitted architect Evgenii Rappoport to build a memorial alley that would terminate near a cargo trolley from the brick factory. The trolley was found in an abandoned part of Admiralteiskii Pond. Thanks to the help of one Saint Petersburg philanthropist, this monument was erected on September 8, 2001, on the sixtieth anniversary of the siege's beginning. Information about it was inscribed on a memorial plaque. In 2004 the Alley of Memory was officially inaugurated. As planned, it started at Victory Street. A posted plaque explained the governmental resolution about the crematorium in the brick factory.

It is important to note that all of these newly erected monuments-the trolley, the rotunda, and the memorial plaque-did not bear any religious symbols and were hardly decorative at all. This is critical. On the one hand, this fact underscored the veterans' respect for historical testimony and for historical artifacts turned monuments. In their eyes, an official resolution about a crematorium or a trolley said more about the history of the place than anything else. The lack of decorations highlighted what the victims believed to be the objective, authentic nature of their knowledge. On the other hand, the deliberate absence of decorative elements suggested an absence of interpretation by the veterans' communities. They failed to use symbolic emblems or language in order to relay the tragedy and sorrow of the siege. They could do no better than to tell their story about this place using the dry, official language of the Soviet bureaucracy.

Thus, commemoration of the burial site in Victory Park originally manifested as secular. However, the veterans' communities were not the only ones vying to control commemoration efforts in Victory Park, although they were the most influential group at the time. Those who supported Orthodox memorials in the park were just as active. Sometimes, the members of these groups were also veterans of the siege who joined local parishes during perestroika, but they also hailed from nationalist groups and parties in Moskovskii District. The activists gathered signatures in favor of building a new church at the site of the brick factory, and they held prayer services at the worship cross, an Orthodox symbol now linked to the memory of the siege.

Despite lending official support for these commemorative initiatives, local authorities had their own plans regarding the park, which abutted the metro station bearing the same name. In the early 1990s an improvised market formed near the metro station. The markets and shopping pavilions that sprung up around the Victory Park metro station irritated the veterans. They wrote letters to the municipal leadership asking that the commercial kiosks be removed. The city authorities officially supported the veterans, but in fact yielded to the shop owners and consented 
to plans for building a shopping mall in Victory Park. When this information went public, a big scandal erupted. Different civic and cultural leaders wrote open letters to the municipal authorities, and the shopping mall was put on hold for several years.

The struggle against the commercial development of the park united Orthodox activists, interested in a new church, with veterans, who regarded the church as "a minor evil." In 2001 they together founded the Saint Petersburg Social Foundation for the Protection of the Moskovskii District Victory Park, under the leadership of Pavel Burov, a candidate for the position of deputy in the nationalist party Rus' and later a member of the State Duma's committee on the veterans' affairs. ${ }^{20}$ In an interview with the Russian Orthodox information agency Russkaia Liniia (the Russian Way), he described the struggle for the church and the opposition to it among the foundation's activists and city authorities. ${ }^{21}$

Thanks to the efforts of the foundation's activists, the church became a topic of public conversation for the first time in 2005, on the eve of the sixtieth anniversary of the Victory in the Second World War. The group's founders proposed to those organizing the celebrations in Saint Petersburg that they establish a new memorial, commemorating all those who perished in the war, in the form of a Russian Orthodox church and a museum of military glory similar to those on the Poklonnaia Hill in Moscow. This was supposed to be an option that would suit all parties involved in the discussions around Victory Park and that would appeal to everybody's ideological outlooks.

The municipal authorities disregarded this request, most likely because there were not enough funds in the budget allocated for the sixtieth anniversary celebration. And so, the worship cross remained the sole orthodox symbol in Victory Park for more than ten years. Besides, while the idea of protecting the park from commercial development found strong support from the population, the erection of a Russian Orthodox church did not have such unequivocal approval.

In a 2009 interview with the information agency Interfax, the head of an Orthodox journalists' club, Aleksandr Shchipkov, reported that there had been several acts of vandalism to the wooden worship cross in Victory Park, which led Russian Orthodox activists to mount a metal cross there. ${ }^{22}$ Moreover, their larger reconstruction plans were discussed on the internet. One of the readers of the news site Gazeta.SPb wrote:

The Russian Orthodox Church already plans to build a huge house of prayer instead of a chapel. Then they will, as usual, declare the territory around the building to be their own property and will continue building and turn the park into a

${ }^{20}$ Aleksei Makarkin, “Partiia 'Rus': Patrioty ot piara." Kompromat.ru, August 29, 2003. Retrieved November 8, 2018 (http://www.compromat.net/page_13540.htm).

${ }^{21}$ "Chto napeli Valentine Matvienko ee sovetniki?" Pravoslavnoe informatsionnoe agenstvo Russkaia Liniia, October 27, 2008. Retrieved November 8, 2018 (http://rusk.ru/st.php?idar=179319).

${ }^{22}$ Aleksandr Shchipkov, "Privatizatsiia parka Pobedy—rezul'tat nravstvennogo zatmeniia." Pravoslavnoe informatsionnoe agenstvo Russkaia Liniia, February 3, 2009. Retrieved November 8, 2018 (https://rusk.ru/st.php?idar=154414). 
monastery, removing all monuments to the "godless warriors." I consider the erection of a chapel and a grave cross an insult to the fallen and the dead, who did not refer to themselves as members of the Russian Orthodox faith. ${ }^{23}$

It seems that the Church of all Saints Resplendent in the Russian Land would not have been built if prominent politicians had not been among its supporters and if another scandal around the attempt to privatize the park had not arisen on the eve of the sixty-fifth anniversary of Victory Day. The construction issue was taken up by top city authorities at the last moment. In January 2009, during a conversation with the patriarch, the governor of Saint Petersburg Valentina Matvienko promised to maintain the park's integrity and to allow the first stone of a chapel to be laid in the park, an act that would honor those Leningraders who had fallen during the siege. ${ }^{24}$ As a result, construction began in January 2010 . The project was led by the architect Sergei Shusterman and completed on May 7, 2010. The chapel was sanctified by the Metropolitan of Saint Petersburg and Ladoga Vladimir (Kotliarov).

It is worth mentioning that the construction was carried out without the approval of the municipal committee on the protection of cultural heritage, which had been against commercial development in the park zone. Evidently, this is why the church was called a temporary chapel and the construction was so rapid. Advocates of the chapel hoped that nobody would demolish a religious building and that it would be easier to legalize it when the chapel is already there. And this is indeed what happened. The personal involvement of Governor Matvienko facilitated the issue's resolution. However, not all park monuments were approved. For example, a monument to the Heroic Women of the Great Patriotic War, which was designed for Victory Park in 2003, was not mounted because of this ban on any significant construction in the park. ${ }^{25}$ Therefore, the exception made by city authorities for the Russian Orthodox Church looks deliberate and provides evidence for a special relationship between the city leaders and the church. This also explains the appearance of other church memorials throughout the city, where local history provided plenty of events to commemorate.

Opponents of the church's construction argued that an Orthodox temple could not honor the memory of all the dead, especially those who were atheists or belonged to different religions. In response to this argument the archpriest Aleksei Isaev decided to alter the shape of the cross mounted on top of the church from an Orthodox cross, with a slanted crosspiece near its foot, to the standard cross accepted by all Christians. ${ }^{26}$

23 "V Parke Pobedy mozhet poiavit'sia ne chasovnia, a 'bol'shoi khram-pamiatnik." Gazeta. $\mathrm{SPb}$, October 16, 2009. Retrieved November 8, 2018 (http://www.gazeta.spb.ru/208244-0).

24 “V Peterburge na meste blokadnogo krematoriia poiavitsia khram." Interfax, April 8, 2009. Retrieved November 8, 2018 (http://www.interfax-religion.ru/?act=news\&div=29648).

${ }^{25}$ Kira Obukhova, "Geroicheskie zhenshchiny voiny prodolzhat skitatnia." Fontanka.ru, April 9 , 2010. Retrieved November 8, 2018 (http://www.fontanka.ru/2010/04/09/137/\#comments).

${ }^{26}$ Anna Repina, “V parke Pobedy vozdvigli krest." Vechernii Peterburg, April 21, 2010. Retrieved November 8, 2018 (http://www.vppress.ru/stories/v-parke-pobedy-vozdvigli-krest-7219). 
Thus, the construction of the Church of all Saints Resplendent in the Russian Land represented a compromise between the veterans' associations and the church, which united in a struggle against the park's commercialization. Orthodox discourse did not dominate over the secular initiatives at this time, but it did provide an obvious alternative to the official Soviet language that had been used to commemorate the dead.

The diversity of memorials and monuments in Victory Park shows visitors the variety of collective memories about WWII and the siege at work in the city of Saint Petersburg. ${ }^{27}$ Soviet discourse appears in the Alley of Heroes and on the monument to Zhukov. However, it coexists with the symbols of memory characteristic of the veterans' organizations: the trolley, the rotunda, and the text of the resolution. They coincide with Orthodox sanctities, the worship cross, and the church. All of this speaks to the chaotic, inconsistent, and competitive nature of siege commemoration. Each of the represented concepts inhabits its own space in the park. On the other hand, the memorial zones do speak to overlapping themes in the memory of the siege. The heroism and sacrifice of the Soviet people are stressed by all of the memorials, even if they emphasize different aspects of the hero narrative. The Alley of Heroes, for instance, honors the heroism of those who were twice awarded the title of the Hero of the Soviet Union as well as the mythologized personalities of Soviet heroes Matrosov and Kosmodem'ianskaia. The religious sites emphasize the heroism of the Russian Orthodox faithful during the siege, secretly and openly praying for the victory. The veterans' version of this narrative highlights the heroism of all, living and dead, independent of their age, confession, or behavior under siege.

New discourses of victimization therefore led to the construction of memorial zones within Victory Park in the 1990s. But they supplemented rather than supplanted the existing Soviet discourse. Leningraders who died during the siege and were excluded from the lists of heroes finally were recognized as such thanks to the efforts of veterans' organizations and their struggle for compensation. New information, like the declassification of the city's true wartime mortality rate, was disclosed in the 1990s. But this did not force a reconsideration of prior interpretations of the siege. The history of the memorialization efforts in Victory Park testifies to this. The act of commemorating the victims still provides a pretext for speaking about the heroism of the living.

\section{CONCLUSION}

The ultimate endgame of agents of historical politics was not to erect monuments or hold public commemorations dedicated to the Siege of Leningrad, even though they did both between 1990 and 2000. Rather, during those years they seized upon memory of the Leningrad siege as a way to claim a public role for themselves, to receive economic benefits (as in the case of societies of the siege survivors), or to

${ }^{27}$ Iurii Piriutko, "Pamiatniki Velikoi Otechestvennoi voiny v Leningrade-Sankt-Peterburge." Munitsipal'nyi okrug Piskarevka (http://mo-piskarevka.spb.ru/publ6/info/98). 
establish and legitimize their own political parties (as in the case of the nationalist Kovalevskii). The appearance of new siege memorials in Saint Petersburg demonstrates the importance and influence that such agents of historical politics acquired. They filled a vacuum left by official authorities who initially seemed uninterested in controlling memorialization of the blockade. The many and diverse forms that commemoration of the siege took, as well as the wide variety of actors who created these versions of the past, were possible only in time of what I have called, following Paperny, Culture Two. Only under such conditions could historical actors from the community, not just official authorities, shape the cultural landscape of the city so indelibly.

Representations of the war and the siege were expressed through the language of socialist realism, which has remained the sole language through which such state and nonstate actors have talked about the siege. The chief way to describe this event, therefore, has revolved around the heroic feats of the city's inhabitants and defenders. In this way, it made no fundamental difference whether the focus was on the military victory, on the heroic survival of the famine victims, or on Christian triumph. What was essential was heroism. Even though those who conceptualized the memorials did so with different thematic emphases in mind, they used the same language of representation. The appearance of each new monument to the siege acted as a kind of statement through which the project's authors asserted a special role for themselves in the community. However, as authorities during Culture Two began to pay more attention to commemorative policies and practices, they elevated the common thread of these representations-the heroism of the city's defendersto even greater heights. This allowed both state and nonstate actors to join the winning side and become authors of the prevailing interpretation of the past. Monuments that radically diverged from this dominant historical narrative of heroism were simply demolished. ${ }^{28}$ In times when Culture Two dominated, authorities chose to uphold the interpretation that best suited their interests, while other versions of the past were eliminated or otherwise marginalized.

The appearance of new temples in Saint Petersburg demonstrates that the Russian Orthodox Church's version of the past has become more and more popular in modern Russia and among the Russian authorities. A marginal group and viewpoint before perestroika, the Russian Orthodox Church has become a leading agent of historical politics in the span of 25 years. The church's interpretation of the past has become popular for two reasons. First, this is connected to the church's opposition towards the Communist Party, especially during President Boris Yeltsin's time. Second, the church has successfully appealed to national values and its reinterpretation of the Soviet past has disseminated a positive image of the country's twentiethcentury history. This narrative celebrated Leningrad as a city of all-Russian pride and glory, just as it was during Soviet times. As a result, instead of fostering a narrative that defends human rights, appeals to self-reflection, or placates members of the

${ }^{28}$ Leninopad ("Lenin-fall”) that took place in Ukraine during and after the Euromaidan protests is an example of such demolition of divergent monuments (in this case, to Vladimir Lenin). 
siege associations, the Russian Orthodox Church has endorsed a story of the blockade that is full of exploits and heroism and that focuses exclusivity to the fate of Orthodox Russians.

The history of the churches in Malaia Okhta and in Victory Park reveals the connection between Russian Orthodoxy and nationalism. This connection can be gleaned not only in the financing of the church by nationalist politicians, as was the case with the Church of the Assumption of the Blessed Virgin Mary; it also is evident in religious services, where priests interpret the war and the siege solely with reference to the interests of the Russian Orthodox majority. For instance, in the 2009 service that the priest Aleksii Uspenskii held in the Moskovskii District Victory Park on the sixty-fifth anniversary of the lifting of the siege, he spoke at length about the relationship between the events of World War I, the Bolshevik Revolution, and the Siege of Leningrad. The priest suggested that the siege was the wrath of God, His punishment of the people who protested against the legitimate tsarist authorities in 1917. He asked:

how was it possible to protest during the World War?... In twenty-four years after the shameful behavior during the World War I, God demonstrated how it was possible and how it was necessary to defend the city, the country, the people. Today we literally stand on the remains of those who died for our city. But we should remember that many of them were the same people, who twenty-four years before the siege had walked the streets of this city with banners "Down with the war!," "Down with the monarchy!"29

In other words, according to Uspenskii, God punished revolutionaries during the siege but saved those who supported the tsarist authorities. Such interpretations of Russia's past force us to reassess the relationship between the Russian Orthodox Church and the post-Soviet Russian authorities. So too does the church's expressed view that Soviet leaders were mystically reborn from demonic Bolsheviks, a claim that echoes the discourse about the New Martyrs, ${ }^{30}$ and therefore were the right individuals to shepherd the city through the blockade and eventually through the Russian state formation. This narrative of the siege could have emphasized the blunders of the Leningrad city leaders and thus drawn on the categories of tragedy and trauma. Instead, it became a panegyric to the Russian national formation.

${ }^{29}$ Aleksii Uspenskii, “Esli by ne bylo revoliutsii 1917 goda, ne bylo by i Blokady.” Pravoslavnoe informatsionnoe agenstvo Russkaia Liniia, January 28, 2009. Retrieved November 8, 2018 (http:// rusk.ru/st.php?idar=180894).

${ }^{30}$ New Martyrs and Confessors of Russian Orthodox Church is a group of over 1,800 clergymen and believers martyred or persecuted during the Revolution of 1917 and Great Terror. The most famous among them are Tsar Nikolas II and his family, Patriarch Tikhon Belavin, and the like. The Russian Orthodox Church asserts that many of these new martyrs saved Russia from atheism and the enemy during WWII and helped to reconstruct strong Christian state. See more about the meaning of the new martyrs in a report by the Patriarch of Moscow and all Russia Kirill at the opening of the XXV International Educational Christmas Readings, January 25, 2017 (https://psk-mp. ru/100496.html). 
Despite differences in how the siege was explained in Soviet and Russian Orthodox discourses, Soviet officials and the Russian Orthodox clergy both recognized its importance for national-patriotic upbringing. The revolutionary traditions of the Leningraders, which Soviet writers used to explain the successful struggle against the German enemies, were replaced by the Orthodox faith. According to the first explanation, the Leningraders were driven to break and lift the siege by their independent and freedom-loving spirit, manifested during the October Revolution. The religious discourse of the second explanation, however, helps promote the Orthodox faith. Despite this significant divergence in understanding, the Soviet and Russian Orthodox interpretations both uphold the notion that the Leningrad blockade was a page in the glorious history of the city's defenders and inhabitants. Therefore, Russian Orthodox churches as well as Soviet memorials about the Siege of Leningrad were erected not so much to remember the dead as to glorify the living. That is why modern Saint Petersburg tour guides bring tourists to Russian Orthodox churches and to Soviet memorials with equal willingness. They do not need to look for new interpretations of the event. All of them are pretty much the same.

\section{REFERENCES}

Adamovich, Ales', and Daniil Granin. [1979] 1994. Blokadnaia kniga. Saint Petersburg: Pechatnyi dvor.

Alexander, Jeffrey C. 2002. "On the Social Construction of Moral Universals: The 'Holocaust' from War Crime to Trauma Dram." European Journal of Social Theory 5(1):5-85.

Assmann, Aleida. 1999. Erinnerungsräume: Formen und Wandlungen des kulturellen Gedächtnisses. Munich: Beck.

Assmann, Aleida. [2006] 2014. Dlinnaia ten' proshlogo: Memorial'naia kul'tura i istoricheskaia politika. Moscow: Novoe literaturnoe obozrenie.

Blum, Alan. 2005. Kak eto delalos'v Leningrade: Tsenzura v gody ottepeli, zastoia i perestroiki, 19531991. Saint Petersburg: Akademicheskii proekt.

Bogumit, Zuzanna. 2010. "Kresty i kamni: Sovetskie simvoly konstruirovaniia pamiati o Gulage." Neprikosnovennyi zapas 71(3):11-29.

Danilova, Nataliya. 2015. The Politics of War Commemoration in the United Kingdom and Russia. Houndmills, UK: Palgrave Macmillan.

Dzeniskevich, Andrei. 1998. Blokada i politika: Oborona Leningrada v politicheskoi kon"iunkture. Saint Petersburg: Nestor-Istoriia.

Forest, Benjamin, and Juliet Johnson. 2002. “Unraveling the Threads of History: Soviet-Era Monuments and Post-Soviet National Identity in Moscow." Annals of the Association of American Geographers 92(3):524-547.

Gabovich, Mikhail. 2015. "Pamiatnik i prazdnik: Etnografiia Dnia Pobedy." Neprikosnovennyi zapas 101(3). Retrieved November 8, 2018 (http://magazines.russ.ru/nz/2015/3/9g.html).

Halbwachs, Maurice. [1925] 2007. Sotsial'nye ramki pamiati. Moscow: Novoe izdatel'stvo.

Johnson, Nuala. 1995. "Cast in Stone: Monuments, Geography, and Nationalism." Environment and Planning D: Society and Space 13(1):51-65.

Kaspe, Irina. 2018. "Mesto smerti: Memorializatsiia voiny i obrazy leningradskoi blokady." Pp. 335-389 in V soiuze s utopiei: Smyslovye rubezhi pozdnesovetskoi kul'tury. Moscow: Novoe literaturnoe obozrenie.

Kelly, Catriona. 2011. “The 'Leningrad Affair': Remembering the 'Communist Alternative' in the Second Capital." Slavonika 17(2):103-122.

Kirschenbaum, Lisa A. 2006. The Legacy of the Siege of Leningrad, 1941-1995: Myth, Memories, and Monuments. New York: Cambridge University Press. 
Luk'ianov, Iurii. 1985. Rubezhi stoikosti i muzhestva. Leningrad: Lenizdat.

Merridale, Catherine. 2002. Night of Stone: Death and Memory in Twentieth-Century Russia. London: Granta Books.

Misztal, Barbara A. 2003. Theories of Social Remembering. Maidenhead, PA: Open University Press.

Mitchell, Katharyne. 2003. "Monuments, Memorials, and the Politics of Memory." Urban Geography 24(5):442-459.

Mitrofanova, Anastasiia. 2016. “Russian Ethnic Nationalism and Religion Today." Pp. 104-131 in The New Russian Nationalism: Imperialism, Ethnicity and Authoritarianism 2000-2015, edited by Pål Kolstø and Helge Blakkisrud. Edinburgh: Edinburgh University Press.

Mitrokhin, Nikolai. 2004. Russkaia pravoslavnaia tserkov': Sovremennoe sostoianie i aktual'nye problemy. Moscow: Novoe literaturnoe obozrenie.

Nora, Pierre. 1989. "Between Memory and History: Les Lieux de Mémoire." Representations 26:724.

Osborne, Brian S. 2006. “From Native Pines to Diasporic Geese: Placing Culture, Setting Our Sites, Locating Identity in a Transnational Canada." Canadian Journal of Communication 31(1):147175.

Paperno, Irina. 2009. Stories of the Soviet Experience: Memoirs, Diaries, Dreams. Ithaca, NY: Cornell University Press.

Paperny, Vladimir. [1985] 1996. Kul'tura dva. Moscow: Novoe literaturnoe obozrenie.

Paperny, Vladimir. 2002. Architecture in the Age of Stalin: Culture Two. Cambridge: Cambridge University Press.

Poretskina, El'ga. 1985. Stoikosti i muzhestvu geroev: Pamiatniki i memorial'nye doski Leningrada, posviashchennye Pobede v Velikoi Otechestvennoi voine. Spravochnik. Leningrad: Lenizdat.

Rusinova, Ol'ga. 2006. “Dolgovechnee kamnia i bronzy: Obrazy blokady v monumental'nykh ansambliakh Leningrada." Pp. 335-366 in Pamiat' o blockade: Svidetel'stva ochevidtsev $i$ istoricheskoe soznanie obshchestva. Moscow: Novoe izdatel'stvo.

Ryleva, Anna, and Natal'ia Konradova. 2005. "Geroi i zhertvy: Memorialy Velikoi Otechestvennoi." Neprikosnovennyi zapas 2-3:40-41.

Shenk, Frit'of Beniamin. 2007. Aleksandr Nevskii v russkoi kul'turnoi pamiati: Sviatoi, pravitel', natsional'nyi geroi (1963-2000). Moscow: Novoe literaturnoe obozrenie.

Sobchak, Anatolii. 1999. Iz Leningrada v Peterburg vo vremeni i prostranstve. Saint Petersburg: Kontrofors.

Snychev, Ioann. 1996. Samoderzhavie dukha: Ocherki russkogo samosoznaniia. Saint Petersburg: Tsarskoe delo.

Tumarkin, Nina. 1994. The Living and the Dead: The Rise and Fall of the Cult of World War II in Russia. New York: Basic Books.

Voronina, Tatjana. 2011. "Heroische Tote Die Blockade, die Opferzahl und die Erinnerung." Osteuropa 8-9:155-167.

Voronina, Tatiana. 2012. “Die Schlacht um Leningrad: Die Verbände der Blockade-Überlebenden und ihre Erinnerungspolitik von den 1960er. Jahren bis heute." Jahrbuecher fuer Geschichte Osteuropas 60(1):1-19.

Voronina, Tatiana. 2018. Pomnit' po-nashemu: Sotsrealisticheskii istorizm i blokada Leningrada. Moscow: Novoe literaturnoe obozrenie. 


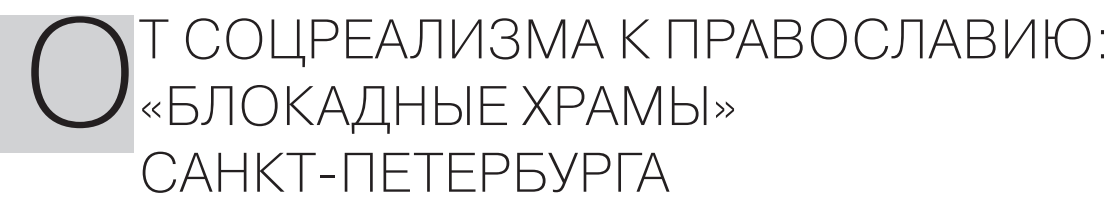

\section{Татьяна Воронина}

Татьяна Воронина - кандидат исторических наук, исследователь в Универcumeme Цюриха (Швейцария). Адрес для переписки: Universität Zürich, Forschungsstelle für Sozial- und Wirtschaftsgeschichte, Rämistrasse 64, 8001 Zurich, Switzerland. tatiana.voronina@hist.uzh.ch.

В статье, основанной на анализе расположенных в Санкт-Петербурге архитектурномемориальных комплексов, посвященных блокаде Ленинграда, рассматривается процесс формирования и изменения исторической памяти об этом событии в городском пространстве. Автора интересует, каким образом светский язык художественной репрезентации блокады, созданный в годы существования СССР, инструментализировался агентами исторической политики в канун перестройки и переосмысливается в категориях православного дискурса в современной России. Следя за культурными трансформациями, происходившими в годы перестройки, автор выделяет новых акторов исторической политики в эти годы: общества ленинградских блокадников, российских националистов и Русскую православную церковь (РПЦ). Именно они были инициаторами появления в 1990-е - начале 2000-х годов в Санкт-Петербурге и его окрестностях многих мемориалов и знаков, посвященных блокаде Ленинграда.

Возникновение православных храмов в память о блокаде - Храма Успения Пресвятой Богородицы (Малая Охта) и Храма Всех Святых в Земле Русской Просиявших (парк Победы) - свидетельствует о появлении нового языка исторической коммеморации в пространстве постсоветского Санкт-Петербурга. Это также говорит о включении блокады в категорию событий, значимых для исторического нарратива РПЦ. На примере описания политики РПЦ в области коммеморации блокады в 1990е годы автор прослеживает причины, по которым бывший в перестройку маргинальным агент исторической политики смог не только обозначить свое присутствие в культурном пространстве города, но и стал претендовать на место наиболее влиятельного интерпретатора прошлого в современной России.

Исследовательский метод автора включает анализ изобразительных форм мемориалов, посвященных блокаде Ленинграда, обстоятельства возникновения памятников, их местонахождение в городе и дискурсивное значение, придаваемое мемориалам в городском сообществе. Статья написана на стыке изучения истории памяти и исследования культуры.

Ключевые слова: историческая память; блокада Ленинграда; архитектура; процесс коммеморации; Русская православная церковь; общества блокадников 